\title{
Control of Ailanthus altissima Using Stem Herbicide Application Techniques
}

\author{
Joseph M. DiTomaso and Guy B. Kyser
}

\begin{abstract}
Three herbicides were tested using four stem application techniques for control of both single trunks and clumps of tree-of-heaven [Ailanthus altissima (Miller) Swingle]. Imazapyr, triclopyr, and glyphosate were applied using cut stump, stump injection, and stem injection techniques. Imazapyr and triclopyr were also applied as a basal bark treatment. Treatments were compared against manual cutting and untreated controls. Untreated cut stems did not provide control of tree-of-heaven. Cut stump treatment with imazapyr and triclopyr $(20 \% \mathrm{v} / \mathrm{v}$ in oil) resulted in more than $90 \%$ reduction in both vigor ratings and resprouting of single stems and clumps. In contrast, stump injection applications were ineffective with all herbicides. For stem injection treatments, undiluted imazapyr gave the best results ( $>95 \%$ canopy reduction), but glyphosate also provided excellent control (92\% canopy reduction). Removing stems 4, 8, or 12 months after treatment did not impact the level of control with imazapic. Imazapic at half the standard rate also gave good control of multistemmed clumps. Basal bark treatments with imazapyr or triclopyr $(20 \% \mathrm{v} / \mathrm{v}$ in oil) gave equally good results, providing nearly complete control. Triclopyr is less selective than imazapyr and thus offers a better option when desirable vegetation surrounds the stems. These results provide several effective options for the control of tree-of-heaven in both urban and riparian sites.
\end{abstract}

Key Words. Ailanthus; basal bark; cut stump; glyphosate; herbicide control; imazapyr; invasive tree; manual cutting; riparian; stem injection; stump injection; tree-of-heaven; triclopyr.

Tree-of-heaven [Ailanthus altissima (Miller) Swingle] is native to eastern Asia. In 1751, it was brought to England (Feret 1985) and in 1784 was introduced to Philadelphia in the United States as an ornamental (Wyman 1951). It was again imported to Long Island in 1790 and its use as a cultivated plant quickly expanded into the eastern and midwestern United States (Feret 1985).

It has been postulated that tree-of-heaven was first introduced to California and other western states as an ornamental in the 1800s with the Chinese who immigrated during the Gold Rush (McClintock 1981) or were used to build the western rail systems (Feret 1985). By the early 1900s, treeof-heaven declined in popularity owing to a number of factors. It resprouts prolifically from both shallow spreading roots and cut stumps, so that once established, it is difficult to remove. In addition, the foliage produces an unpleasant odor, which is associated with headaches and nausea. The leaves or leaf leachates can also cause dermatitis with vesicular eruptions (Burrows and Tyrl 2001), and the pollen is a known allergen (Blumstein 1943).

Despite decreased popularity, tree-of-heaven escaped cultivation and expanded its range in most of the United States (Merriam 2003; DiTomaso and Healy 2006). It is currently established in urban waste areas, old dwellings and mining settlements, roadsides, utility rights-of-way, pastures, and disturbed forest sites (Burch and Zedaker 2003). In the eastern United States, tree-of-heaven has also established in forests where it has been shown to create dense stands and outcompete native woody species (Knapp and Canham 2000; Call and Nilsen 2005). In California, it is a highly invasive tree in riparian areas as well as grassland and woodland sites (Hunter 2000, Kelly 2001). It can survive from sea level to at least $1585 \mathrm{~m}(5,231 \mathrm{ft})$ under a broad range of soil conditions but generally grows best in areas where soil moisture is not limiting (Feret 1985).

Tree-of-heaven is a shade-intolerant species that grows rapidly and quickly establishes in the gaps of forest or riparian areas (Knapp and Canham 2000). Although seedlings cannot survive under a dense canopy, root sprouts grow slowly and survive for years under an intact canopy (Kowarik 1995). Once released by the development of a gap, these clonal ramets can rapidly establish. When exposed to light, new shoots can grow up to $1.8 \mathrm{~m}(5.94 \mathrm{ft})$ in length in a single season and can eventually reach heights of nearly $18 \mathrm{~m}(59.4$ ft) (Feret 1985).

Although a number of factors contribute to the competitive ability of tree-of-heaven, it may outcompete other species through the production of quassinoids that act as allelochemicals (Heisey 1990; Lawrence et al. 1991; Heisey 1996; Heisey and Heisey 2003). The most active of these compounds is 
ailanthone, which is most concentrated in the root and stem bark (Heisey 1996; De Feo et al. 2003).

Control of tree-of-heaven can be difficult. Manual cutting or girdling the cambial tissue of the stem generally stimulates stump and root sprouting as a result of the loss of apical dominance, resulting in an increase in overall stand density (Kelly 2001; Burch and Zedaker 2003). Herbicides have also been tested for tree-of-heaven control in several studies. Hexazinone applied as a foliar treatment gave varied levels of control (55\% to $93 \%$ at 2.4 to $9.6 \mathrm{~kg} \cdot \mathrm{ha}$ [2.1-8.6 lb.ac]) 21 months after treatment (Pritchard 1981). However, it is not registered for use near water and is not an option in riparian areas. Foliar application of the growth regulator herbicide triclopyr (Butler and Britting 1998) and glyphosate applied with a rope wick applicator to the foliage also provide control (Butler and Britting 1998).

For more mature woody plants, low-volume basal bark treatments of triclopyr, picloram, and imazapyr were used to control tree-of-heaven in Virginia (Burch and Zedaker 2003). Two years after treatment, optimal control was achieved with a combination of triclopyr and picloram. Triclopyr and imazapyr alone or in combination also gave some control, but not as effectively as combinations with picloram. Picloram is not registered for use in California nor is it registered near water in any region of the country. Thus, like hexazinone, it is not a control option in most areas of the west where treeof-heaven has invaded riparian sites. In a California study, Kelly (2001) reported a triclopyr basal bark treatment to be very effective (98\% control) on tree-of-heaven.

Large woody plants can also be controlled using a cut stump technique, in which the herbicide is applied directly to the cambial regions of the newly cut stem. It is widely recommended that application of the herbicide be made within 30 min after cutting (Tjosvold and McHenry 1986). A combination of picloram and 2,4-D as a cut stump treatment was found to be ineffective for control of tree-of-heaven (Pritchard 1981). In contrast, triclopyr and glyphosate showed good results in one study (Butler and Britting 1998) with only a few plants resprouting after a cut stump treatment. However, in another report (Kitz 1997), these same herbicides did not provide effective control with a cut stump treatment.

In our study, we examine several stem treatment techniques for the control of tree-of-heaven. We compare the effectiveness of three herbicides (triclopyr, glyphosate, and imazapyr), all with formulations registered for use in riparian habitats or systems adjacent to water. We evaluated the effectiveness of cut stump, basal bark, stem injections, and stump injection treatments as well as untreated mechanical cutting. In addition, we examine the timing of removing trees after a stem injection treatment and the timing of herbicide application after cutting the stems. The objective is to provide land managers with the most effective option for tree-of- heaven control in sensitive habitats near water and to expand the control options available in other infested sites such as urban settings.

\section{MATERIALS AND METHODS}

\section{Treatment Sites}

The initial stem injection trial was conducted on the campus of the University of California, Davis, along the relict (now dry) south fork of lower Putah Creek at $\approx 15 \mathrm{~m}(\approx 49.5 \mathrm{ft})$ elevation. This area has a warm Mediterranean climate with a mean yearly precipitation of $480 \mathrm{~mm}$ (19.2 in), most of it during the winter season.

The subsequent study, designed to compare different herbicides and application techniques, was conducted on California Department of Fish and Game property along Putah Creek in western Yolo County at $\approx 60 \mathrm{~m}(\approx 198 \mathrm{ft})$ elevation. This region has a warm Mediterranean climate with a mean annual precipitation of $584 \mathrm{~mm}$ (23.36 in) (86\% between November and March). Trees were located along a small fluvial terrace, 10 to $80 \mathrm{~m}$ ( 33 to $264 \mathrm{ft}$ ) distant from the creek and 5 to $10 \mathrm{~m}$ ( 16.5 to $33 \mathrm{ft}$ ) above the mean creek level. This infestation has been present for approximately 20 years and originated with ornamental plantings at a home site a short distance upstream. The native vegetation consisted of blue oak woodland dominated by blue oak (Quercus douglasii) and foothill pine (Pinus sabiniana) in the uplands and by Goodding's black willow (Salix gooddingii), California black walnut (Juglans californica), and seepwillow (Baccharis salicifolia) closer to the creek.

\section{Treatment Parameters}

The initial trial was conducted at two locations in the University of California, Davis, Riparian Preserve. For all treatments at this site, individual plants were treated as replicates with eight replicates per treatment at each site. Tree-ofheaven plants were treated with one of two commercial formulations of imazapyr by a stem injection technique (Table 1). Because it has been reported that the effectiveness of foliar treatments of imazapyr on saltcedar (Tamarix ramosissima) is compromised unless the plants are left uncut for 2 years after treatment (Duncan and McDaniel 1998), we compared the effect of the herbicide on plants cut below the stem injection site 4, 8, and 12 months after treatment.

At the first site, we selected trees in three size classes, small (4 to $8 \mathrm{~cm}$ [1.6 to $3.2 \mathrm{in}$ ] trunk diameter at knee height), medium ( 8 to $16 \mathrm{~cm}$ [3.2 to $6.4 \mathrm{in}$ ] diameter at knee height), and clumps with three to eight trunks branching below knee height. Only the clumps were left uncut. The emulsifiable concentrate formulation of imazapyr (Stalker [BASF Corp., Research Triangle Park, NC]; 239.7 g.ae [acid equivalent]/L; $2 \mathrm{lb} \cdot \mathrm{ae} / \mathrm{gal})$ was used at this location. At the second site, we selected only medium trees ( 8 to $16 \mathrm{~cm}$ [3.2 to $6.4 \mathrm{ft}$ ] diameter at knee height). In this location, we used the water- 
Table 1. Chemical techniques, location, timing, treatment, carrier, and rate used to control tree-of-heaven.

\begin{tabular}{|c|c|c|c|c|c|}
\hline Treatment method & Treatment location & Year of October & Herbicide (trade name) & Carrier & Rate \\
\hline \multirow[t]{2}{*}{ Stem injection } & University of California, Davis & 1998 & Imazapyr (Stalker) & None & Undiluted \\
\hline & & 1998 & Imazapyr (Habitat) & None & Undiluted \\
\hline \multirow[t]{3}{*}{ Cut stump } & Putah Creek & 2001 & Glyphosate (Roundup Pro) & $50 \%$ water & $50 \%$ \\
\hline & & 2001 & Imazapyr (Chopper) & $80 \%$ Hasten oil & $20 \%$ \\
\hline & & 2001 & Triclopyr (Garlon 4) & $80 \%$ Hasten oil & $20 \%$ \\
\hline \multirow[t]{3}{*}{ Stem injection } & Putah Creek & 2001 & Glyphosate (Roundup Pro) & None & Undiluted \\
\hline & & 2001 & Imazapyr (Chopper) & None & Undiluted \\
\hline & & 2001 & Triclopyr (Garlon 4) & None & Undiluted \\
\hline \multirow[t]{3}{*}{ Stump injection } & Putah Creek & 2001 & Glyphosate (Roundup Pro) & None & Undiluted \\
\hline & & 2001 & Imazapyr (Chopper) & None & Undiluted \\
\hline & & 2001 & Triclopyr (Garlon 4) & None & Undiluted \\
\hline \multirow[t]{2}{*}{ Basal bark } & Putah Creek & 2001 & Imazapyr (Chopper) & $80 \%$ Hasten oil & $20 \%$ \\
\hline & & 2001 & Triclopyr (Garlon 4) & $80 \%$ Hasten oil & $20 \%$ \\
\hline
\end{tabular}

soluble formulation of imazapyr (Habitat [BASF Corp., Research Triangle Park, NC]; $239.7 \mathrm{~g} \cdot \mathrm{ae} / \mathrm{L} ; 2 \mathrm{lb} \cdot \mathrm{ae} / \mathrm{gal}$ ), which is registered for use in riparian areas and adjacent to water. Trees at both sites were treated on 23 October 1998, in autumn before leafdrop.

In the Putah Creek site in Yolo County, California, we tested four treatment methods for control of tree-of-heaven using three herbicides. Treatments were made shortly before leafdrop in late October 2001. Herbicides tested included the emulsifiable concentrate of imazapyr (Chopper [BASF Corp., Research Triangle Park, NC]; 239.7 g.ae/L; 2 lb·ae/gal), the ester formulation of triclopyr (Garlon 4 [DOW AgroSciences LLC, Indianapolis, IN]; $479.3 \mathrm{~g} \cdot \mathrm{ae} / \mathrm{L} ; 4 \mathrm{lb} \cdot \mathrm{ae} / \mathrm{A}$ ), and glyphosate (Roundup Pro [Monsanto Co., St. Louis, MO]; 359.5 $\mathrm{g} \cdot \mathrm{ae} / \mathrm{L} ; 3 \mathrm{lb} \cdot \mathrm{ae} / \mathrm{gal})$. Methods included stem injection, cut stump, stump injection, and basal bark treatments. In addition, we included untreated plants for each treatment. Individual trees were treated as replicates with six to eight trees per treatment. Trees were represented by three size classes (trunks $<8 \mathrm{~cm}$ [ $<3.2 \mathrm{in}]$ diameter, trunks $>8 \mathrm{~cm}$ [ $>3.2$ in], and multiple trunks). At least two trees from each size category were included in each treatment.

Because trees were randomly dispersed along each of these riparian areas, treatments at each site were organized in a complete randomized block design. Individual trees were marked with plastic flagging and numbered with aluminum tags.

\section{Treatments Techniques}

\section{Cut Stump}

Trees were cut $60 \mathrm{~cm}$ (24 in) above the soil surface using a chain saw. The stump cambium was treated with an herbicide solution consisting of 20\% v/v Chopper in Hasten crop oil, $20 \%$ v/v Garlon 4 in Hasten oil, or 50\% v/v Roundup Pro in water (Table 1). The herbicide solution was applied using a laboratory Nalgene squeeze bottle. An average of $5 \mathrm{~mL}$ total solution (range from 3 to $25 \mathrm{~mL}$ [ 0.09 to $0.75 \mathrm{fl} \mathrm{oz}$ ] depend- ing on tree size) was used per stump (3.6 cm [ $\approx 1.4$ in] diameter average stump size), which wet the cambial ring short of runoff down the stem. Stumps were treated at four intervals after cutting $(0,15,30$, and $60 \mathrm{~min})$.

\section{Stem Injection}

The stem injection technique, also known as hack-and-squirt, consisted of making a downward angled 4 to $8 \mathrm{~cm}$ long (1.6 to 3.2 in) hatchet mark (hack) in the bark 30 to $45 \mathrm{~cm}$ (12 to 18 in) above the soil surface and then injecting $1 \mathrm{~mL}[0.03 \mathrm{fl}$ oz] of undiluted herbicide (Chopper, Garlon 4, or Roundup Pro) into the mark using a disposable $10 \mathrm{~mL}(0.30 \mathrm{fl} \mathrm{oz})$ pipette and pipette pump (Table 1). The standard rate was one hack and herbicide treatment for every $8 \mathrm{~cm}$ (3.2 in) in trunk diameter. For the tree clumps, the standard dose was based on the accumulated stem diameter (total of all stems) of all trunks, but applications were made at lower rates of one-half or one-fourth the standard rate. These lower rates were used because it was considered impractical to apply herbicide to each stem within every clump. For example, a clump with four $8 \mathrm{~cm}$ (3.2 in) stems (standard rate of four injections, one on each stem) would receive either two injections, one each on two stems (one-half rate) or one injection on one stem (one-fourth rate). We also established control trees of all sizes, which were also marked with the hatchet but were not treated.

\section{Stump Injection}

Trees were cut with a chainsaw similar to the cut stump treatment. A hatchet mark and undiluted herbicide treatment (Chopper, Garlon 4, or Roundup Pro) was then made to the stump as described for the stem injection treatment (Table 1). The herbicide application was performed either immediately, $1 \mathrm{hr}, 1$ day, or 1 week after the tree was cut to test whether a delay between cutting and treatment would affect efficacy.

\section{Basal Bark}

Similar to the stem injection treatment, this technique left the tree standing. Only imazapyr and triclopyr were used in this 
treatment, because glyphosate is not lipophilic and cannot be mixed in oil. An oil carrier is necessary to penetrate the tree bark. Either Chopper or Garlon 4 (20\% in Hasten oil) was applied to cover the basal $45 \mathrm{~cm}$ (18 in) of the tree trunk using a bottle sprayer. Trunks were sprayed to wet but not to runoff. An average of $60 \mathrm{~mL}$ of total solution was applied to each tree.

\section{Evaluations and Analysis}

At the University of California, Davis, site, each tree (replicate) was visually estimated for percent crown reduction 8 (June 1999) and 21 months (July 2000) after treatment. Evaluation of percent crown reduction in all trees were based on a relative comparison of foliage canopy in an undamaged tree. In addition, measurements were made of the percentage of trees with resprouts as well as the number and height of resprouting stems.

In the Putah Creek site, visual estimates of percent canopy reduction and canopy vigor were determined in August 2002 (10 months after treatment) and August 2003 (22 months after treatment) for each tree. Vigor measurements were visual estimates based on comparison with undamaged foliage of untreated trees and ranged from 0 (dead) to 10 (undamaged). In addition, the percentage of trees that resprouted was recorded and resprout vigor, number, and height were visually evaluated or measured.

For standing-tree treatments, canopy reduction and vigor were compared across all treatments (including uncut con- trols) using analysis of variance (ANOVA), and means were separated using the Student-Newman-Keuls (SNK) test ( $\alpha=$ 0.05). For stump treatments, the presence or absence of stump sprouts was compared across herbicide types, within each parent treatment technique, using logistic regression $(\alpha=$ 0.05). Vigor of stump sprouts (including stumps with no sprouts, which were assigned a vigor rating of 0 ) was compared using ANOVA and SNK. Cut-stump subtreatments (time interval between cutting and herbicide application) were compared within each herbicide and within each parent application technique using logistic regression and ANOVA. Time subtreatments were grouped by herbicide within each parent application technique after it was determined that time interval had no effect.

\section{RESULTS AND DISCUSSION}

At the University of California, Davis site, manual cutting used alone provided little, if any, control of tree-of-heaven. By 10 months after cutting, small and large stumps produced between three and nine new basal sprouts (Table 2). By 21 months after cutting, $\approx 25 \%$ to $30 \%$ of the cut trees died, but the remainder averaged $\approx 4$ new sprouts per stump. These new sprouts were an average of 1.6 to $2 \mathrm{~m}(5.3$ to $6.6 \mathrm{ft})$ in height. Burch and Zedaker (2003) also showed that mechanical cutting stimulated tree-of heaven resprouting (1.6 new sprouts per stump) and increased overall stand density. They similarly showed that $21 \%$ of the cut stump trees failed to resprout.

Table 2. Tree-of-heaven control using stem injection treatment with undiluted imazapyr as an emulsifiable concentrate (Stalker) or water-soluble (Arsenal) formulation ${ }^{2}$.

\begin{tabular}{|c|c|c|c|c|c|c|c|}
\hline \multirow[b]{2}{*}{ Treatment } & \multirow[b]{2}{*}{$\begin{array}{l}\text { Cutting } \\
\text { date }\end{array}$} & \multicolumn{2}{|c|}{ Evaluation 8 MAT* } & \multirow[b]{2}{*}{$\begin{array}{l}\text { Percent of } \\
\text { stumps } \\
\text { with sprouts }\end{array}$} & \multicolumn{3}{|c|}{ Evaluation 21 MAT } \\
\hline & & $\begin{array}{l}\text { Mean } \\
\text { number } \\
\text { of sprouts }\end{array}$ & $\begin{array}{l}\text { Mean crown } \\
\text { reduction } \\
(\%)\end{array}$ & & $\begin{array}{l}\text { Mean number } \\
\text { of sprouts on } \\
\text { sprouting stumps }\end{array}$ & $\begin{array}{l}\text { Mean height } \\
\text { of sprouts } \\
\text { (m) }\end{array}$ & $\begin{array}{l}\text { Crown } \\
\text { reduction } \\
(\%)\end{array}$ \\
\hline \multicolumn{8}{|l|}{ Imazapyr (Stalker) } \\
\hline \multirow[t]{3}{*}{ Small trees $(4-8 \mathrm{~cm}$ diameter) } & 4 MAT & 0 & - & & & & \\
\hline & 8,12 MAT & - & $97.9 \pm 5.2$ & & & & \\
\hline & & & & 12.5 & 1.0 & 0.4 & - \\
\hline \multirow[t]{2}{*}{ Medium trees $(8-16 \mathrm{~cm}$ diameter $)$} & 4 MAT & 0 & - & & & & \\
\hline & 8,12 MAT & - & $96.9 \pm 4.4$ & & & & \\
\hline Clumps, $1 / 2$ dose & - & - & $84.2 \pm 14.6$ & - & - & - & $99.3 \pm 0.6$ \\
\hline Clumps, $1 / 4$ dose & - & - & $76.0 \pm 8.9$ & - & - & - & $81.7 \pm 18.9$ \\
\hline \multirow[t]{3}{*}{ Untreated small trees } & 4 MAT & $2.75 \pm 3.10$ & - & & & & \\
\hline & 8,12 MAT & - & 0 & & & & \\
\hline & & 70.8 & 3.8 & 1.6 & - & & \\
\hline \multirow{2}{*}{ Untreated medium trees } & 4 MAT & $2.75 \pm 2.50$ & - & & & & \\
\hline & 8,12 MAT & - & 0 & & & & \\
\hline \multicolumn{8}{|l|}{ Imazapyr (Habitat) } \\
\hline \multirow[t]{2}{*}{ Medium trees $(8-16 \mathrm{~cm}$ diameter) } & 4 MAT & 0 & - & 8.3 & 1.0 & 0.6 & - \\
\hline & 8, 12 MAT & - & $94.8 \pm 5.8$ & & & & \\
\hline \multirow{2}{*}{ Untreated medium trees } & 4 MAT & $9.25 \pm 4.27$ & - & 75.0 & 4.0 & 2.0 & - \\
\hline & 8,12 MAT & - & $26.3 \pm 37.4$ & & & & \\
\hline
\end{tabular}

*Months after treatment $(4$ MAT $=$ February 1999; 8 MAT $=$ June 1999; 12 MAT = October 1999, 21 MAT = July 2000). 
Both formulations of imazapyr were very effective for the control of small and medium trees using stem injection. Crown reduction was between $95 \%$ and $98 \%$ with either the water-soluble (Habitat) or emulsifiable concentrate (Stalker) formulation of imazapyr 10 months after treatment (Table 2). Because imazapyr is known to translocate slowly, it was postulated that a single winter season would not be sufficient to allow the herbicide to circulate throughout the tree and give adequate control. With saltcedar or tamarisk (Tamarix spp.), it was demonstrated that plants could not be cut until two full growing seasons after foliar treatment (Duncan and McDaniel 1998). However, with tree-of-heaven there was no difference between trees cut down at 4,8 , or 12 months after treatment and no difference between the two formulations of imazapyr by 21 months after treatment. At this evaluation timing, only $12.5 \%$ and $8.3 \%$ of the Stalker- and Habitat-treated plants, respectively, had stump sprouts. In addition, sprouts were about four times fewer in number and four times smaller than resprouts from the mechanically cut trees without an herbicide treatment.

Stem injection treatment of tree clumps with half of the standard rate of Stalker gave $84 \%$ crown reduction 8 months after treatment and 99\% reduction 21 months after treatment (Table 2). The quarter rate, however, gave only $82 \%$ crown reduction, which is was not considered to be satisfactory control.

Our results indicate that imazapyr applied as a stem injection treatment can be an effective method for tree-of-heaven control even with plants growing in clumps. In some cases, it also was observed that imazapyr appeared to move from treated stems to other adjacent trees, presumably through root grafts. Symptoms of imazapyr injury were evident in other untreated tree-of-heaven stems up to $\approx 5 \mathrm{~m}(16.5 \mathrm{ft})$ away from the treated stem. This phenomenon has been observed in other trees. A similar response was noted in black oak (Quercus kelloggii) after a stem injection imazapyr treatment (DiTomaso et al. 2004). Despite this response within tree-ofheaven plants, we observed no injury resulting from root grafting among other species.

In our second study, we compared the effect of imazapyr, triclopyr, and glyphosate on tree-of-heaven using stem injection, stump injection, cut stump, and basal bark treatments. As was the case with the University of California, Davis, site, mechanical cutting gave very poor control with $\approx 86 \%$ of the stumps producing new sprouts (Table 3). By 2003, 22 months after cutting, stumps averaged 6.0 new sprouts with a mean height of $2.4 \mathrm{~m}(7.9 \mathrm{ft})$.

Although it is widely believed that herbicide should be applied to the stump immediately after cutting (Tjosvold and McHenry 1986), our results indicate that a delay between cutting and herbicide treatment in both the cut stump and the stump injection techniques did not significantly affect the percentage of trees with sprouts (Figure 1) or the vigor of the new sprouts (Figure 2). Applying the herbicide $1 \mathrm{hr}$ after cutting gave the same result as an application immediately after cutting in the cut stump treatments. In the stump injection technique, applying the herbicide 1 week after cutting also provided the same level of control as applying the stem injection immediately after cutting. Based on these results, data for different timing intervals were combined for each herbicide in the cut stump and stump injection treatments.

Using a cut stump technique, imazapyr and triclopyr both provided excellent results. Although glyphosate results were statistically better than the cut controls, they did not give adequate tree-of-heaven control. By $2003, \approx 41 \%$ of the glyphosate-treated trees resprouted and the resprouts were a similar height $(2.5 \mathrm{~m}[8.3 \mathrm{ft}])$ as the untreated trees $(2.4 \mathrm{~m}$ [7.9 ft]). Triclopyr produced slower results but was equal to

Table 3. Results for cut-tree treatments in 2001 tree-of-heaven trial' .

\begin{tabular}{|c|c|c|c|c|c|c|c|c|c|c|c|}
\hline & & & & & & \multicolumn{6}{|c|}{ Means for sprouts ${ }^{\mathrm{v}}$} \\
\hline & & \multicolumn{2}{|c|}{ Vigor mean over all trees $\mathrm{s}^{\mathrm{y}, \mathrm{x}}$} & \multicolumn{2}{|c|}{ Percent of trees with sprouts ${ }^{\mathrm{w}}$} & \multicolumn{2}{|c|}{ Vigor } & \multicolumn{2}{|c|}{ Number } & \multicolumn{2}{|c|}{ Height (m) } \\
\hline & & 2002 & 2003 & 2002 & 2003 & 2002 & 2003 & 2002 & 2003 & 2002 & 2003 \\
\hline \multirow{3}{*}{$\begin{array}{l}\text { Cut } \\
\text { stump }\end{array}$} & Glyphosate & $2.5 \mathrm{~b}$ & $4.1 \mathrm{~b}$ & $33.5 \mathrm{~b}$ & $40.8 \mathrm{~b}$ & 7.5 & 9.9 & 3.9 & 2.9 & 1.0 & 2.5 \\
\hline & Imazapyr & $0.0 \mathrm{c}$ & $0.6 \mathrm{c}$ & $3.1 \mathrm{c}$ & $9.8 \mathrm{c}$ & 0.5 & 6.3 & 0.0 & 2.8 & - & 0.7 \\
\hline & Triclopyr & $1.0 \mathrm{bc}$ & $0.5 \mathrm{c}$ & $21.0 \mathrm{bc}$ & $6.7 \mathrm{c}$ & 4.3 & 7.5 & 1.8 & 1.5 & 0.4 & 0.6 \\
\hline \multirow{4}{*}{$\begin{array}{l}\text { Cut control } \\
\text { Stump } \\
\quad \text { injection }\end{array}$} & & $8.3 \mathrm{a}$ & $7.4 \mathrm{a}$ & $85.7 \mathrm{a}$ & $85.7 \mathrm{a}$ & 9.7 & 8.7 & 7.3 & 6.0 & 1.1 & 2.4 \\
\hline & Glyphosate & $6.7 \mathrm{a}$ & $6.6 \mathrm{ab}$ & $85.7 \mathrm{a}$ & $92.9 \mathrm{a}$ & 8.0 & 7.1 & 5.5 & 4.2 & 0.8 & 1.7 \\
\hline & Imazapyr & $0.9 \mathrm{~b}$ & $1.5 \mathrm{c}$ & $35.8 \mathrm{c}$ & $32.1 \mathrm{c}$ & 2.1 & 4.0 & 6.1 & 6.3 & 0.2 & 0.7 \\
\hline & Triclopyr & $4.8 \mathrm{a}$ & $5.0 \mathrm{~b}$ & $60.7 \mathrm{~b}$ & $62.5 \mathrm{~b}$ & 7.9 & 7.7 & 3.3 & 2.4 & 0.4 & 1.2 \\
\hline \multicolumn{2}{|l|}{ Cut control } & $8.3 \mathrm{a}$ & $7.4 \mathrm{a}$ & $85.7 \mathrm{ab}$ & $85.7 \mathrm{ab}$ & 9.7 & 8.7 & 7.3 & 6.0 & 1.1 & 2.4 \\
\hline
\end{tabular}

${ }^{\mathrm{z}}$ All evaluations made in August 2002 and 2003. Values are means over all application timings. Within each treatment group, values followed by the same letter are not different at $\alpha=0.05$. Cut control values were used for separate comparisons with cut stump and stump injection treatments.

${ }^{\mathrm{y}}$ Vigor is a visual evaluation scale where $0=$ dead, $10=$ healthy.

${ }^{\mathrm{x}}$ Differences determined by analysis of variance and Student-Newman-Keuls test.

${ }^{\mathrm{w}}$ Differences determined by logistic regression.

${ }^{\mathrm{v}}$ Only for trees with resprouting. 


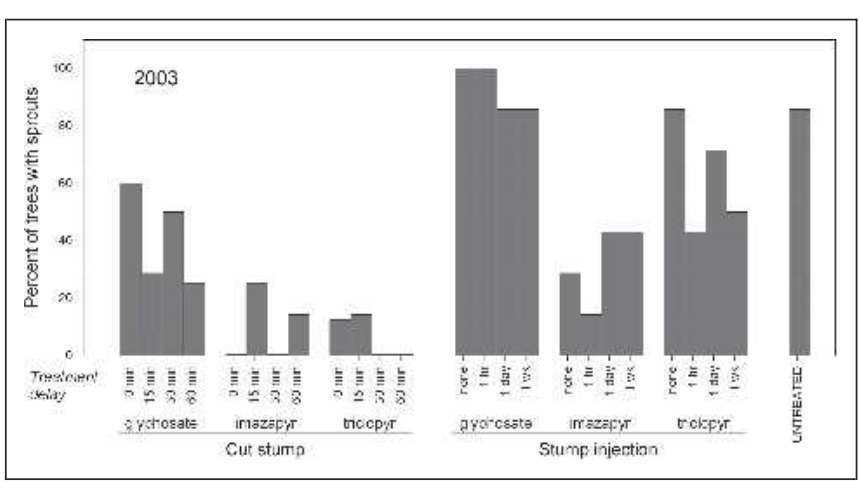

Figure 1. Effect of herbicide timing intervals for cut stump and stump injection techniques on the percent of trees with sprouts. There were no significant differences ( $\alpha=$ 0.05 ) for any of the timings within each herbicide treatment.

that of imazapyr by the second season after treatment. In 2003 , sprouting occurred on only $6.7 \%$ and $9.8 \%$ of stumps treated with triclopyr and imazapyr, respectively, and vigor was significantly lower than sprouts on untreated and glyphosate-treated stumps. In those stumps that did produce sprouts after imazapyr or triclopyr treatment, the number of sprouts averaged between 1.5 and 2.8 and the sprout vigor rating showed that they were fairly healthy in the second season after treatment. This indicates that plants that do resprout are likely to recover over time and would require retreatment by either a foliar herbicide application or a basal bark treatment.

Other reports on tree-of-heaven control with cut stump treatments have shown mixed results. Kitz (1997) noted that land managers had difficulty controlling tree-of-heaven with cut stump treatments using glyphosate and triclopyr. In contrast, Butler and Britting (1998) reported effective control with few resprouts after cut stump treatments with

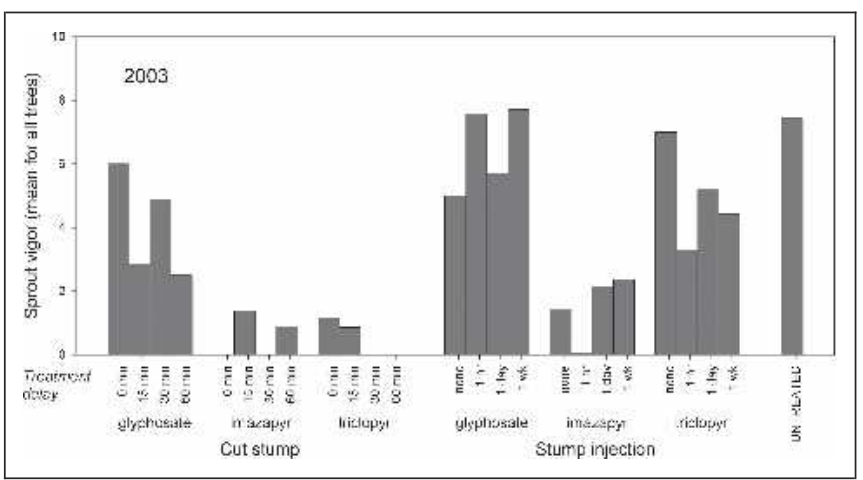

Figure 2. Effect of herbicide timing intervals for cut stump and stump injection techniques on the vigor of resprouts. There were no significant differences $(\alpha=0.05)$ for any of the timings within each herbicide treatment. either glyphosate or triclopyr. However, neither of these studies provided quantitative data for control, efficacy, or evaluation.

We also examined the impact of mechanical cutting followed by stem injection treatment of the standing stump. By combining aspects of cut stump with stem injection treatments, we hoped to provide a method that could extend the application window after cutting. This would be advantageous in situations in which cutting and treatment operations are performed by separate teams. However, no herbicides provided adequate control of tree-of-heaven with this technique. Although imazapyr was statistically the best of the three herbicides tested, nearly $36 \%$ of the treated stumps resprouted the next season, and this value was similar in the second season after treatment (Table 3). The success of conventional stem injection treatments may depend on the vascular system remaining intact and distributing herbicide more effectively throughout the tree.

Tree-of-heaven treated by either stem injection or basal bark were left intact for the 2 year duration of this study. Herbicide-treated plants were compared with uncut control plants. Although the control plants did not receive a treatment, a few died spontaneously both in the first season (2002) and second season (2003) of the study (Table 4). Triclopyr did not provide effective control with a stem injection treatment. The level of canopy reduction and vigor with a triclopyr treatment was not statistically different from the uncut control plants in the second season after treatment. By comparison, both glyphosate and imazapyr gave good to excellent control with imazapyr proving to be the best treatment. In the second season after treatment, imazapyr resulted in $100 \%$ tree-of-heaven mortality, whereas glyphosate provided $\approx 92 \%$ canopy reduction and a vigor rating of 1.5.

Stem injection gives land managers a number of advantages in riparian areas. For example, the treatment requires minimal equipment, applicators can treat large areas quickly, little herbicide is used, drift potential is very low, and some dead standing trees can be left for bird habitat. In addition, crews can remove the dead trees during the off-season after the leaves have senesced, when removal operations are not be encumbered by the additional weight and litter of the attached leaves.

Basal bark treatments with $20 \% \mathrm{v} / \mathrm{v}$ of either triclopyr or imazapyr also resulted in excellent control of tree-of-heaven. By the second season after treatment, imazapyr completely killed all treated trees, regardless of the stem size (Table 4). Triclopyr also gave complete control of larger trees, but even smaller trees that were not killed showed very low levels of canopy vigor $(<2.0)$.

Burch and Zedaker (2003) also tested basal bark treatments for tree-of-heaven control. They likewise demonstrated $100 \%$ control with the same rate of triclopyr (Garlon 4), and 
Table 4. Results for standing-tree treatments in 2001 tree-of-heaven trial'

\begin{tabular}{|c|c|c|c|c|c|c|}
\hline \multirow[b]{2}{*}{ Treatment method } & \multirow[b]{2}{*}{ Herbicide } & \multirow[b]{2}{*}{ Tree size } & \multirow{2}{*}{$\frac{\text { Canopy }}{2002}$} & \multirow{2}{*}{$\frac{\text { Percent reduction }}{2003}$} & \multicolumn{2}{|c|}{ Canopy vigor ${ }^{\mathrm{y}}$} \\
\hline & & & & & 2002 & 2003 \\
\hline \multirow[t]{2}{*}{ Stem injection } & Glyphosate & - & $82.3 \mathrm{ab}$ & $91.7 \mathrm{a}$ & $2.3 \mathrm{~b}$ & $1.5 \mathrm{~b}$ \\
\hline & Triclopyr & - & $66.7 \mathrm{~b}$ & $31.4 \mathrm{~b}$ & $6.2 \mathrm{a}$ & $6.7 \mathrm{a}$ \\
\hline \multirow[t]{2}{*}{ Basal bark } & Imazapyr & $<4 \mathrm{~cm}$ dia & $100.0 \mathrm{a}$ & $100.0 \mathrm{a}$ & $0.0 \mathrm{~b}$ & $0.0 \mathrm{~b}$ \\
\hline & & $>4 \mathrm{~cm}$ dia & $99.8 \mathrm{ab}$ & $100.0 \mathrm{a}$ & $0.1 \mathrm{~b}$ & $0.0 \mathrm{~b}$ \\
\hline Uncut control & & - & $12.5 \mathrm{c}$ & $27.1 \mathrm{~b}$ & $8.8 \mathrm{a}$ & $7.6 \mathrm{a}$ \\
\hline
\end{tabular}

${ }^{\mathrm{z}}$ All canopy percent reduction and vigor measurements made in August of 2002 and 2003. Within each treatment group, values followed by different letters are different at $\alpha=5 \%$ (analysis of variance, Student-Newman-Keuls test).

${ }^{\mathrm{y}}$ Vigor determined by visual evaluation on scale of $0=$ dead and $10=$ healthy.

they reported that 9\% v/v Stalker (imazapyr) gave 100\% mortality 1 year after treatment. However, their evaluation 2 years after treatment showed that combinations of triclopyr and picloram resulted in the best aboveground control and also prevented resprouting by eliminating the existing root system. As previously discussed, picloram is not registered for use in California nor is it registered for use around riparian areas in any state.

Kelly (2001) also achieved mortality of greater than $98 \%$ in tree-of-heaven with a basal bark treatment of $25 \% \mathrm{v} / \mathrm{v}$ Garlon 4 in oil.

Although both triclopyr and imazapyr showed similar results with basal bark applications, imazapyr has a much longer soil residual activity (field half-life of 25 to 142 days) compared with triclopyr (field half life of 10 to 46 days) (Vencill 2002). In addition, imazapyr is a broader-spectrum herbicide compared with the broadleaf selective herbicide triclopyr. Consequently, either because of overspray or because of herbicide washing off the trunk, trees treated with imazapyr often developed a "dead zone" of approximately 1 $\mathrm{m}(3.3 \mathrm{ft})$ diameter around the base of the trunk. Thus, triclopyr may be a less phytotoxic choice for basal bark applications.

Like stem injection, basal bark applications require minimal equipment and are easily performed by one person. However, this technique requires more herbicide than other treatments. Basal bark treatment of an average stem in this study (diameter $9 \mathrm{~cm}$ [3.6 in]) required $12 \mathrm{~mL}(0.36 \mathrm{fl} \mathrm{oz})$ of formulated triclopyr or imazapyr compared with only $1 \mathrm{~mL}$ $(0.03 \mathrm{fl} \mathrm{oz})$ of herbicide product for either a cut stump or stem injection treatment.

\section{CONCLUSIONS}

The control of tree-of-heaven can be difficult, particularly in riparian areas. Mechanical cutting used alone is not a good management tool and is likely to increase the infestation.
However, the results presented here demonstrate that herbicide stem treatments can be effectively used for the control of this invasive species. All stem treatment techniques are best applied in late summer or fall, when carbohydrates are translocating to the belowground tissues, including the root buds (Tjosvold and McHenry 1986). An advantage to all of these stem application methods is the low risk of off-site movement through spray drift. However, it should be noted that under very hot conditions, some vapor drift may be expected with the ester formulations.

A cut stump technique would be most appropriate with very large trees or clumps having a well-developed bark. The bark of these plants would be difficult to penetrate with the stem injection method and would not likely absorb herbicide using a basal bark treatment. When crews are available to cut, treat, and remove the stems over a short time period, a cut stump treatment is a very efficient technique for tree-ofheaven control. We have demonstrated that both triclopyr and imazapyr are effective and both herbicides can be applied within $1 \mathrm{hr}$ of cutting without loss of efficacy. Imazapyr as the water-soluble formulation Habitat is registered for use near aquatic environments and can be an excellent choice in riparian areas. In this study, we used the ester formulation of triclopyr (Garlon 4), which is not registered for use near water. However, the water-soluble formulation (Garlon 3A) is registered near water and would be expected to provide a similar level of control in a cut stump treatment.

The stem injection technique was also very effective for the control of individual tree-of-heaven trees or clumps. Either a water-soluble (Habitat) or emulsifiable concentrate (Stalker) formulation was equally effective, but only Habitat is registered near water. Glyphosate, which has formulations registered for use near water, also provided good control but was not as consistent as imazapyr. This technique can be an advantage when tree removal is not necessary at the time of treatment. It would allow crews to concentrate on treatments 
in the late summer or fall and conduct tree removal at least 4 months later during the winter or early spring. Another advantage of this technique is that less herbicide is used compared with the basal bark method.

Like the stem injection method, basal bark treatments with imazapyr and triclopyr can also be used in situations in which immediate tree removal is not necessary. The technique is most appropriate in sites where numerous smaller stems $(<10$ $\mathrm{cm}[<4$ in] diameter) are present but is not recommended in areas with large plants that have a thick bark. Like with the stem injection method, basal bark treatments require minimal equipment. Other studies have also shown triclopyr to be effective in a basal bark application, and this is probably a better choice when other desirable vegetation surrounds the trees or small clumps. It is necessary to use the ester formulation of triclopyr and the emulsifiable concentrate of imazapyr to get effective control of tree-of-heaven with a basal bark application. However, both of these formulations are not registered for use near water, so this technique is not appropriate in areas directly adjacent to aquatic sites.

Although we did directly measure the effect of cut-stem treatments on stump sprouting, we do not know what impact these treatments have on sucker sprouting from spreading roots. The effectiveness of these treatments on root sprouting would depend on the ability of the herbicide to translocate long distances. This may need to be considered in a follow-up program to ensure that the infestation does not reestablish.

Acknowledgments. The authors thank Craig Stowers and Joel Trumbo at the California Department of Fish and Game, Dan Tolson at the University of California Natural Reserve System, Ron Unger at EDAW, Inc., and Rich Marovich with Putah Creek Streamkeeper for their assistance in conducting this project.

\section{LITERATURE CITED}

Blumstein, G.I. 1943. Sensitivity to Ailanthus pollen. The Journal of Allergy 14:329-334.

Burch, P.L., and S.M. Zedaker. 2003. Removing the invasive tree Ailanthus altissima and restoring natural cover. Journal of Arboriculture 29:18-24.

Burrows, G.E., and R.J. Tyrl. 2001. Toxic Plants of North America. Iowa State Univ. Press. Ames, IA.

Butler, E., and S. Britting. 1998. Mapping and control of weeds in the American River Parkway. Proc., California Exotic Pest Plant Council Sym. 4:60-63.

Call, L.J., and E.T. Nilsen. 2005. Analysis of interactions between the invasive tree-of-heaven (Ailanthus altissima) and the native black locust (Robinia pseudoacacia). Plant Ecology 176:275-285.

De Feo, V., L. DeMartino, E. Quaranta, and C. Pizza. 2003. Isolation of phytotoxic compounds from tree-of-heaven
(Ailanthus altissima Swingle). Journal of Agricultural and Food Chemistry 51:1177-1180.

DiTomaso, J.M., and E.A. Healy. 2007. Weeds of California and Other Western States. Univ. California, Div. Agr. Nat. Res. Oakland, CA.

DiTomaso, J.M., G.B. Kyser, and E.A. Fredrickson. 2004. Control of black oak and tanoak in the Sierra Nevada range. Western Journal of Applied Forestry 19:268-276.

Duncan, K.W., and K.C. McDaniel. 1998. Saltcedar (Tamarix spp.) management with imazapyr. Weed Technology, a Journal of the Weed Science Society of America 12: 337-344.

Feret, P.O. 1985. Ailanthus: Variation, cultivation, and frustration. Journal of Arboriculture 11:361-368.

Heisey, R.M. 1990. Evidence for allelopathy by tree-ofheaven (Ailanthus altissima). Journal of Chemical Ecology 16:2039-2055.

- 1996. Identification of an allelopathic compound from Ailanthus altissima (Simaroubaceae) and characterization of its herbicidal activity. American Journal of Botany 83:192-200.

Heisey, R.M., and T.K. Heisey. 2003. Herbicidal effects under field conditions of Ailanthus altissima bark extract, which contains ailanthone. Plant and Soil 256:85-99.

Hunter, J. 2000. Ailanthus altissima (Miller) Swingle, pp. 32-36. In Invasive Plats of California's Wildlands. Bossard, C.C., J.M. Randall, and M.C. Hoshovsky, Eds. Univ. of California Press. Berkeley.

Kelly, M. 2001. Results of basal bark applications of Garlon 4 on Ailanthus altissima (tree-of-heaven). Proc., California Exotic Pest Plant Council Sym. 6:105-107.

Kitz, J. 1997. A working paper on Ailanthus. Cal-EPPC News 5:9.

Knapp, L.B., and C.D. Canham. 2000. Invasion of an oldgrowth forest in New York by Ailanthus altissima: Sapling growth and recruitment in canopy gaps. The Journal of the Torrey Botanical Society 127:307-315.

Kowarik, I. 1995. Clonal growth in Ailanthus altissima on a natural site in West Virginia. Journal of Vegetation Science 6:853-856.

Lawrence, J.G., A. Colwell, and O.J. Sexton. 1991. The ecological impact of allelopathy in Ailanthus altissima (Simaroubaceae). American Journal of Botany 78:948-958.

McClintock, E. 1981. Trees of Golden Gate Park: Tree-ofheaven, Ailanthus altissima. Pacific Horticulture 42: $16-18$.

Merriam, R.W. 2003. The abundance, distribution and edge associations of six non-indigenous, harmful plants across North Carolina. The Journal of the Torrey Botanical Society 130:283-291. 
Pritchard, G.H. 1981. Spot-gun application of hexazinone for the control of tree of heaven (Ailanthus altissima), pp. 113-114. Proc., Sixth Australian Weeds Conf. B.J. Wilson and J.T. Swarbrick, Eds. Queensland, Australia.

Tjosvold, S.A., and W.B. McHenry. 1986. How to kill unwanted trees, shrubs, and resprouting stumps in the landscape. Coop. Ext. Univ. Calif., Div. Agr. Nat. Res. Publ. \#7166.

Vencill, W.K. (Ed.). 2002. Herbicide Handbook. 8th Ed. Weed Sci. Soc. Am., Lawrence, KS.

Wyman, D. 1951. Trees for American Gardens, MacMillan Co. New York.

Joseph M. DiTomaso (corresponding author)

Department of Plant Sciences, Mail Stop 4

One Shields Ave.

University of California

Davis, CA 95616, U.S.

jmditomaso@ucdavis.edu

Guy B. Kyser

Department of Plant Sciences, Mail Stop 4

One Shields Ave.

University of California

Davis, CA 95616, U.S.

Résumé. Trois herbicides ont été testés au moyen de quatre techniques d'application pour contrôler à la fois les troncs uniques ainsi que les massifs d'ailanthe glanduleux (Ailanthus altissima (Miller) Swingle). L'imazapyr, le triclopyr et le glyphosate ont été appliqués au moyen des techniques d'injection dans la tige, d'injection dans la souche et d'injection sur la surface de coupe. L'imazapyr et le triclopyr ont aussi appliqués sous forme de traitement par la base sur l'écorce. Les traitements ont été comparés par rapport à une coupe manuelle et un groupe témoin sans intervention. Les tiges coupées mais non traitées n'ont pas donné de résultat quant au contrôle de l'ailanthe glanduleux. Le traitement par injection sur la surface de coupe avec l'imazapyr et le triclopyr (20\% en v/v dans de l'huile) a donné plus de $90 \%$ de diminution à la fois dans les taux de vigueur et de rejets à partir des tiges uniques ou des talles de tiges. En comparaison, les applications par injection dans la souche ont été inefficaces avec tous les herbicides. Pour les traitements par injection dans la tige, l'imazapyr non dilué à donné les meilleurs résultats ( $>95 \%$ de réduction du couvert végétal), mais le glyphosate a aussi permis d'obtenir un excellent contrôle ( $92 \%$ de réduction du couvert végétal). La coupe des tiges 4,8 ou 12 mois après le traitement n'a pas eu d'impact sur le degré de contrôle avec l'imazapyr. L'imazapyr à un taux de moitié par rapport au standard a aussi donné un bon contrôle des talles arbustives. Les traitements par la base sur l'écorce avec l'imazapyr ou le triclopyr (20\% en v/v dans de l'huile) ont donné des résultats équivalents en produisant un contrôle quasi complet. Le triclopyr est moins sélectif que l'imazapyr qui offre de ce fait une meilleure option lorsque de la végétation désirable entoure les tiges. Ces résultats donnent certaines options effectives pour le contrôle de l'ailanthe glanduleux à la fois sur les sites urbains et riverains.

Resumen. Se probaron tres herbicidas usando cuatro técnicas de aplicación al tronco para el control de árboles aislados y grupos de árboles de Ailanthus altissima (Miller) Swingle. Fueron aplicados Imazapyr, triclopyr, y glyphosate usando corte de tocones, inyección al tocón y técnicas de inyección al tronco. Imazapyr y triclopyr también fueron aplicados como tratamientos a la corteza basal. Los tratamientos fueron comparados contra corta manual y controles no tratados. Los tallos de cortes no tratados no dieron un control del Ailanthus. El tratamiento de corta de tocones con imazapyr y triclopyr (20\% v/v en aceite) resultó en más del $90 \%$ de reducción en tallos y en rebrotes, tant o en árboles solos como en grupo. En contraste, las aplicaciones de inyección al tocón fueron inefectivas con todos los herbicidas. Para los tratamientos de inyección al tallo, imazapyr dió los mejores resultados (>95\% de reducción de copa), pero glyphosate también dio excelente control (92\% de reducción de copa). La remoción de los tallos 4, 8 o 12 meses después del tratamiento no impactó el nivel de control con imazapic. Imazapic a la mitad de la tasa estándar también dio buen control de grupos multitallos. Los tratamientos a la corteza basal con imazapyr o triclopyr $(20 \% \mathrm{v} / \mathrm{v}$ en aceite) dieron igualmente buenos resultados, proporcionando casi un completo control. Triclopyr es menos selectivo que imazapyr y por tanto ofrece una mayor opción cuando hay vegetación alrededor de los tallos. Estos resultados proporcionan varias opciones efectivas para el control del Ailanthus en sitios riparios y urbanos.

Zusammenfassung. Es wurden drei Herbizide mit vier Applikationstechniken für die Kontrolle von Einzelbäumen und Gruppen von Ailanthus altissima. Imazapyr, Triclopyr und Glyphosat wurden appliziert durch einen Stammschnitt, Stumpfinjektion und Stamminjektionstechniken. Imazapyr und Triclopyr wurden auch noch als basale Rindenapplikation getestet. Die Behandlungen wurden verglichen mit Rückschnitt und unbehandelten Kontrollen. Unbehandelte Stammrückschnitte führten nicht zu einer Kontrolle von Ailanthus. Eine Behandlung der Stumpen mit Imazapyr und Triclopyr ( $20 \% \mathrm{v} / \mathrm{v}$ in Öl) führte zu $90 \%$ Rückgang bei den vorhandenen und nachgetriebenen Einzelbäumen und Gruppen. Im Kontrast waren die Stumpeninjektionen bei allen Herbiziden ohne Erfolg. Für Stamminjektionen gab es die besten Ergebnisse ( $<90 \%$ Kronenreduktion) mit unverdünntem Imazapyr, aber auch Glyphosat zeigte sich sehr effektiv (92\% Reduktion). Eine Entfernung der Stämme 4, 8 oder 12 Monate nach der Behandlung hatte keinen Einfluss auf die Kontrolle durch Imazapic. Imazapic in der halben Standarddosierung führte auch zu einer guten Kontrolle von mehrstämmigen Ailanthus. Die basale Rindenbehandlung mit Imazapyr oder Triclopyr (20\% v/v in Öl) lieferte ähnlich gute Ergebnisse und führte fast zu einer kompletten Kontrolle. Triclopyr ist weniger selektiv als Imazapyr und bietet daher bessere Möglichkeiten, wenn erwünschte Vegetation die Stämme umgibt. Diese Ergebnisse liefern verschiedene effektive Möglichkeiten zur Kontrolle von Ailanthus im städtischen und ländlichen Umfeld. 